\title{
An Insight into the Pathogenesis, Diagnosis and Treatment of SARS-Cov-2 with a Synopsis of Situation in Malaysia during the 2020 Outbreak
}

\author{
Yusuf Wada ${ }^{1,2}$ (D) Zaidah Abdul Rahman ${ }^{1,3^{*}}$ (D) Musa S. Kaware ${ }^{4}$ and Suwaiba Muhammad \\ Ladan $^{5}$, \\ ${ }^{1}$ Department of Medical Microbiology and Parasitology, School of Medical Sciences, Health Campus, \\ Universiti Sains Malaysia 16150 Kubang Kerian, Kelantan Malaysia. \\ ${ }^{2}$ Department of Zoology, Ahmadu Bello University, Zaria Nigeria \\ ${ }^{3}$ Hospital USM, Health Campus, USM, 16150, Kubang Kerian, Kelantan, Malaysia \\ ${ }^{4}$ Department of Community Medicine, College of Medical Sciences, Umaru Musa Yar'adua University, \\ Katsina State Nigeria \\ ${ }^{5}$ Department of Chemical Science, Federal University of Kashere, P.M.B 0182 Gombe, \\ Gombe State, Nigeria. (S.W.L) suwaibana@gmail.com \\ *Corresponding author: Zaidah Abdul Rahman (drzaidah@usm.my)
}

Abstract
Severe acute respiratory syndrome coronavirus 2 (SARS-CoV-2) is the novel coronavirus (CoV) that
emerged from China causing diseases known as COVID-19, mainly involves the respiratory system.
It has ravaged through most of the world causing death in huge numbers. CoVs are zoonotic as
they are transferred from animals to humans. Several animals have been suggested to be the host
for SARS-CoV-2 ranging from bats, camels and pigs. The presence of a type 1 transmembrane
glycoprotein called spike protein is responsible for CoVs' ability to penetrate the host's tissues.
The immune response elicited during the proliferation of SARS-CoV-2 is most largely dependent on
the macrophages, dendritic cells, T-cells and the human epithelial cells which determine the
aftermath and lodging of chemokines and cytokines. The RT-qPCR is the preferred test for the
confirmation of the disease although several Rapid Diagnostic Tests are also in use. Remdesivir,
favilavir, niclosamide and ciclesonide are promising drugs under clinical trial or research to
manage COVID-19. Several vaccines are also under clinical trial phase to mitigate the effect of
COVID-19. Malaysia had its index case on the January $24^{\text {th }}, 2020$ and since then, Malaysia handling
of the pandemic have been superb, well planned out and worthy of emulation from other
countries. They have carried out an unprecedented number of tests surpassing any other country
in the region.
Keywords: diagnosis, Malaysia, pathogenesis, Sars-CoV-2, COVID-19, treatment.

INTRODUCTION

Coronaviruses (CoVs) are RNA viruses that have much higher mutation tendencies than DNA viruses, a factor that has led to their survivability and adaptability (Sanjuán and Domingo-Calap, 2016). CoVs consist of four main groups; Gamma-coronavirus, Deltacoronavirus, Beta-coronavirus and Alphacoronavirus. They also belong to the family viridae, subfamily coronavirinae and order nidovirales (Wang et al., 2014). CoVs genomes are known to code for proteins which speed up their multiplication and proliferation into cells. These proteins are envelop, spike, membrane and nucleocapsid proteins (Garoff et al., 1998). SARS-CoV-2, the novel CoV is an RNA betacoronavirus that has a lot in common with the Middle East Respiratory Syndrome Coronavirus (MERS-CoV) and Severe Acute Respiratory
Syndrome Coronavirus (SARS-CoV) (Raj et al., 2020). It causes coronavirus disease known as COVID-19.

There are three broad divisions of CoVs usually based on their type of host. As stated by Fehr and Perlman (2015), the first division is the human coronavirus 229E (HCoV 229E) and transmissible gastric enteritis virus (TGEV), the second division is another form of human CoVsOC43 (HCoV-OC43), murine hepatitis virus $(\mathrm{MHV})$, and bovine CoVs (BCoV) while the last division consists of infectious bronchitis virus (IBV) of aves. These divisions were rearranged following the appearance in early 2000 of SARSCoVs. These modifications only affected the second division as they were split into $2 \mathrm{~A}$ which represent the original group members and $2 \mathrm{~B}$ which represent the newly seen SARS-CoV, MHV and $\mathrm{BCoV}$ (Hsu et al., 2003). There are 
presently six types of CoVs that have been documented to cause serious human respiratory diseases and they are SARS-CoV, HCoV-OC43, HCoV-229E, HKU1, HCoV-NL63 and MERS-CoV. Following the sudden appearance of several respiratory problems in Wuhan, a city in China, the Government of China on $31^{\text {st }}$ December reported to the World Health Organisation (WHO) and barely two weeks later, Chinese researchers and the WHO announced a novel coronavirus. The virus was thought to first appear in the Wuhan seafood market (Paules et al., 2020). There is however a debate still on about the origin. Symptoms of this virus include shortness of breath, respiratory problems and dry cough. The number of cases has risen astronomical worldwide, with a lot of death and remarkable recoveries. According to WHO, there are currently $6,573,540$ COVID-19 cases with 388,041 deaths and 3,170,505 recoveries as at $4^{\text {th June }} 2020$ (WHO, 2020).

The history of $\mathrm{CoV}$ is an interesting one and dated as far back as the 1960s when it was reported in chickens as a highly infectious form of bronchitis virus. This was subsequently isolated in humans from nasal passages and was called human CoV (229E and OC43) (Pyrc et al., 2007). This was followed by the isolation in 2003 of SARS-CoV and Human coronavirus-NL (HCoV NL63) in 2004. In 2005 and 2012, Human coronavirus-HKU1 (HCoV-HKU1), Middle East Respiratory Syndrome Coronavirus (MERS-CoV) and Severe Acute Respiratory Syndrome Coronavirus (SARS-CoV-2) was identified respectively (To et al., 2013).

CoVs are zoonotic as they are transferred from animals to humans. Several animals have been implicated as being the host for SARS-CoV-2 ranging from bats, camels and pigs (WHO, 2020). Mackay and Arden (2015) stated that the means of transmission of CoV from animals to humans are not clear but humans near these animals are more prone to the infection. Transmission to another human could be by handshakes, close contacts, sneezing and coughing (WHO, 2020)

\section{Pathogenesis}

The presence of a type 1 transmembrane glycoprotein called spike protein is responsible for CoVs' ability to penetrate the body tissues of the host (Xia et al., 2014). On the external sub-domain of the spike protein is the receptorbinding domain (RBD) specifically V484-L567 while a five stranded $B$-sheet arranged in an anti-parallel manner with its mid-region consisting of six helices is located in the midsub-domain. Distinct loops and an anchor at the upper and lower region attaches the RBD to the external sub-domain and core sub-domain respectively (Xia et al., 2014).

Durai, et al. (2015) stated that manifestation of infection is brought about by three near-core chains (HR2) and three central helices (HR1) which stimulates the injection of viral fragments into the cytoplasm. On the surface of the host cell is a supplementary course through which CoV proliferate the cell via proteases that are trans-membranous. Lau et al. (2013) stated that, in CoV, the host protease is responsible for differentiating the spike protein into an $\mathrm{N}$-terminal portion wholly made up of RBD while two heptad repeats, a transmembranous region and a merging peptide make up the $\mathrm{C}$-terminal region.

Due to the efficient proliferation of $\mathrm{CoV}$ into the host cell surface, biopsies and histopathological examination has detected the virus particles in tissues and organs. Alsaad et al. (2018) stated that CoV isolate was detected in the pulmonary tissues of a male patient who had $T$ cell lymphoma during an autopsy. Similarly, Xia et al (2014) also stated that viral isolates can be found in the skeletal muscle, pneumocytes, pulmonary macrophages and epithelial cells of the near renal tubule.

Several mechanisms are responsible for the development of CoV in humans as shown by different studies, prominent among which is the dipeptidyl peptidase-4 (DPP4) mediated mechanism in which the protease attaches to the RBD in CoVs via an a/B-hydrolase domain and an octa bladed B-propeller domain (Drosten et al., 2013). In addition to the structural prowess of DPP4 is also the presence of the main blocker enzyme of the virus spike protein known as adenosine deaminase (Park et al., 2016). The second mechanism is the papain-like protease (PLpro) assisted mechanism which is essential for membrane replication as a result of the activity of $3 \mathrm{C}$-like proteinase and PLpro. In addition to the protease role, this papain mechanism is seen to contain enzymes that serve more than one function. For instance, Rabouw et al. (2016) have shown that one such function is the removal of ISG15 pair and the splitting of ubiquitin in the host cell. Another mechanism of note is the accessory proteins assisted mechanism which are proteins like retinoic acid-inducible gene-1 (RIG-1), endosomal toll-like receptor 3 (TLR3) and protein-5 (MDA5). However, Canton et al. (2018) stated that attachment to the host cell is made possible when the protein p4a is used without RIG-1 and MDA5. 


\section{Immune response}

The immune responses elicited during the proliferation of CoVs are most largely dependent on the macrophages, dendritic cells, T-cells and the human epithelial cells which determine the aftermath and lodging of chemokines and cytokines (Menachery et al., 2014). Menachery et al. (2018) in their study showed that a variable which could prevent transcription mechanisms from pairing to the gene elicitor regions which are primed by interferon is the subdued histone markers as a result of the peculiar changes in the chromatin structure of the CoV infected cells. Yang et al. (2013) also stated that IFN-c- related fluctuation of the antigen-presenting gene is as a result of the changes in the attachment of methyl on the DNA. However, Lau et al. (2013) stated that some proteins that are involved in the pathogenesis of CoV such as PLpro, M, 4a and $4 \mathrm{~b}$ were shown to hamper the inducement of interferon.

In another study, Cong et al. (2018) noted that hampering of viral replication and initiation of $\mathrm{T}$-cells are as a result of the inactivation of $\mathrm{T}$ cells following antigen immersion brought about by underdeveloped dendritic cells. They further observed that viral infections were linked with detained initiation of proinflammatory chemokines and cytokines. Ying et al. (2016) and Huang et al. (2020) stated that elicitation of IL-8, TNF-a, IL-12p40, IL-6, MIP-1a/CCL-3, IP10/CXCL-10, RANTES/CCL-5, MCP-1/CCL-2, IFN-a2 and IFN-a2 which are all pro-inflammatory chemokines or cytokines are notable during macrophage infection in humans.

\section{Promising Drugs and Vaccines for Covid-19 \\ Very recently, the Food and Drug} Administration (FDA) approved the urgent use of remdesivir in the management of COVID-19 (FDA, 2020). Remdesivir has a wide range of activity on viruses and was produced by a company Gilead Sciences (Scavone et al., 2020). It was originally used for the treatment of Ebola and Marburg virus but were found to be ineffective (Scavone et al., 2020). It is administered intravenously and has been shown to affect SARS-CoV and MERS-CoV(Scavone et al., 2020). Prior to remdesivir, chloroquine was also found to have an activity on COVID-19 especially in patients in an advanced stage of the disease by reducing the inflammation. Another study noted multiplication of the virus in cell culture was impeded by chloroquine (Agostini et al.,2018).
Remdesivir exists in its active form as GS-5734 which is a copy of adenosine nucleotide that puzzles the polymerase of viral RNA and resist being decrypted by viral exoribonuclease ultimately leading to a decrease in the manufacture of viral RNA ( $\mathrm{Li}$ and De Clercq, 2020). They further stated that this active form stops viral polymerase action while locking down transcription and viral RNA production.

Till date, there are no specific drugs for the treatment of COVID-19 however, Jeon et al. (2020)screened 49 drugs approved by FDAfor use on SARS-CoV. Interestingly, two of 49 drugs were seen to have antiviral activity and they are ciclesonide which is a corticosteroid used in the treatment of asthma and allergic rhinitis and niclosamide which is an anti-helminthic drug. Ciclesonide is believed to have antiinflammatory action which can prevent cytokine overproduction while niclosamide is seen to have a wide range of antiviral activity (Jeon et al., 2020). Another antiviral drug Favilavir also got the nod to be used as experimental COVID-19 drug and was manufactured by a Chinese company Zhejiang Hisun Pharmaceutical.

Currently, there are no vaccines against COVID19 but efforts are in place to see that a vaccine is produced to bring to a grinding halt this pandemic grappling the whole world. The World Health Organisation (WHO) as stated by Grenfell and Drew, (2020) are looking forward to a vaccine in no less than 18 months and this is assuming all things are working out the way they are supposed to. The production of a vaccine for any disease and especially COVID-19 seeing the urgency needed in curtailing its spread and preventing more deaths is a herculean task. That is why Thanh Le et al. (2020) stated that a global coalition known as the Coalition for Epidemic Preparedness Innovations (CEPI) is at the forefront of this vaccine production. This coalition is putting together at least 2 billion dollars drawn from all over the world for vaccine production. They are optimistic that by early 2021, a vaccine should have been produced and given an emergency use measure. Just recently, Damon (2020) stated that the WHO has been seeking support from rich countries up to the tune of 8 billion dollars for fast vaccine production.

As of April 2020, a good number of vaccine program are in place and some have advanced to the second stage of clinical trials (Thanh Le et al., 2020). Below is a table of vaccine production from different parts of the world. 
Table 1: Some Promising Vaccine Candidates and Progress

\begin{tabular}{|c|c|c|c|c|}
\hline Vaccine name & Country & Producer & Methodology & $\begin{array}{l}\text { Stage } \\
\text { trial }\end{array}$ \\
\hline bacTRL-Spike & Canada & $\begin{array}{l}\text { Symvivo Corporation, } \\
\text { University of British } \\
\text { Columbia, Dalhousie } \\
\text { University }\end{array}$ & $\begin{array}{l}\text { DNA, Oral bacterial } \\
\text { medium }\end{array}$ & Phase I \\
\hline No name & China & $\begin{array}{l}\text { Beijing Institute of } \\
\text { Biological Products, } \\
\text { Wuhan Institute of } \\
\text { Biological Products }\end{array}$ & $\begin{array}{l}\text { inactivated COVID- } \\
19 \text { virus (vero cells) }\end{array}$ & Phase I \\
\hline Covid-19/aAPC & China & $\begin{array}{l}\text { Shenzhen Geno- } \\
\text { Immune } \\
\text { Institute }\end{array}$ & $\begin{array}{l}\text { lentiviral vector, } \\
\text { pathogen-specific } \\
\text { artificial antigen } \\
\text { showing dendritic } \\
\text { cells }\end{array}$ & Phase I \\
\hline LV-SMENP-DC & China & $\begin{array}{l}\text { Shenzhen Geno- } \\
\text { Immune } \\
\text { Institute }\end{array}$ & $\begin{array}{l}\text { lentiviral minigene } \\
\text { vaccine, dendritic } \\
\text { cells modified with } \\
\text { a lentiviral vector }\end{array}$ & Phase I \\
\hline Ad5-nCoV & China & $\begin{array}{l}\text { CanSino Biologics, } \\
\text { Institute of } \\
\text { Biotechnology of the } \\
\text { Academy of Military } \\
\text { Medical Sciences }\end{array}$ & $\begin{array}{l}\text { recombinant } \\
\text { adenovirus type } 5 \\
\text { vector }\end{array}$ & Phase II \\
\hline Ad5-nCoV & China & $\begin{array}{l}\text { CanSino Biologics, } \\
\text { Institute of } \\
\text { Biotechnology of the } \\
\text { Academy of Military } \\
\text { Medical Sciences }\end{array}$ & $\begin{array}{l}\text { recombinant } \\
\text { adenovirus type } 5 \\
\text { vector }\end{array}$ & Phase I \\
\hline $\begin{array}{l}\text { ChAdOx1 nCoV- } \\
19\end{array}$ & United Kindom & University of Oxford & adenovirus vector & Phase I-II \\
\hline $\begin{array}{l}\text { BNT162 (a1, b1, } \\
\text { b2, c2) }\end{array}$ & $\begin{array}{l}\text { Germany and the } \\
\text { United States }\end{array}$ & $\begin{array}{l}\text { BioNTech, } \text { Fosun } \\
\text { Pharma, Pfizer }\end{array}$ & RNA & Phase I-II \\
\hline No name & China & Sinovac Biotech & $\begin{array}{l}\text { inactivated SARS- } \\
\text { CoV-2 virus }\end{array}$ & Phase I-II \\
\hline INO-4800 & $\begin{array}{l}\text { The United } \\
\text { States and South } \\
\text { Korea }\end{array}$ & $\begin{array}{l}\text { (Inovio } \\
\text { Pharmaceuticals, } \\
\text { CEPI, Korea National } \\
\text { Institute of Health, } \\
\text { International Vaccine } \\
\text { Institute) }\end{array}$ & $\begin{array}{lr}\text { DNA } & \text { plasmid } \\
\text { delivered } & \text { by } \\
\text { electroporation }\end{array}$ & Phase I-II \\
\hline mRNA-1273 & United States & $\begin{array}{l}\text { Moderna, US National } \\
\text { Institute of Allergy } \\
\text { and } \\
\text { Diseases }\end{array}$ & $\begin{array}{l}\text { lipid nanoparticle } \\
\text { dispersion } \\
\text { containing } \\
\text { messenger RNA }\end{array}$ & Phase I \\
\hline
\end{tabular}

\section{Diagnosis}

COVID-19 is diagnosed either by detecting the presence of SARS-CoV-2 genetic materials or antibodies produced as a result of the infection. Reverse Transcriptase real-time Polymerase Chain Reaction (RT-qPCR) is the recommended method by WHO and widely used UMYU Journal of Microbiology Research worldwide. Serological tests for the detection of antibodies are carried out by Enzyme-Linked Immunosorbent Assay (ELISA) and rapid diagnostic test (RDT) (Abbasi, 2020). Serological test can help to ascertain the herd immunity among population, however, the usefulness of immune response to prevent www.ujmr.umyu.edu.ng 
infections are still under investigation. This antibody test is important because it is able to detect both cases with and without symptoms of the disease.

\section{A. PCR Based or Molecular Based Methods \\ i. Reverse Transcriptase real-time Polymerase Chain Reaction (RT- qPCR)}

Currently, RT-qPCR is considered the gold standard for the detection and confirmation of SARS-CoV-2.The test relies on the use of a fluorescent DNA labelling method for investigating gene expression and measurement of viral RNA at both local and universal scale (Abbasi, 2020). Five types of probes are employed in the detection of SARS-CoV-2 using RT-qPCR by producing a fluorescent signal. They are TaqMan, molecular beacons, scorpion, SYBR Green and multiplex probes. The TaqMan probes, molecular beacons and scorpions solely relies on the Förster Resonance Energy Transfer (FRET) coupling of the dye molecule and a quencher moiety to the oligonucleotide substrates while the SYBR Green relies on the binding of the double-stranded DNA (Holden and Wang, 2008). The multiplex, however, allows the simultaneous measurements of molecular beacons, TaqMan probes and scorpions in one tube (Ratcliff et al., 2007). The comparative threshold and the standard curve method are the two most used methods in the analysis of the result obtained (Bustin, 2005).

The Center for disease control (CDC) stated that sputum and swabs from the nasopharynges are samples needed for the test to be carried out and that results only takes two days at most (CDC, 2020). Drosten (2020) stated that sometimes, viral isolates present in the throat are capable of vanishing while they replicate in the lungs. This usually happens in the first few days of the COVID-19 and the throat swab would be the most appropriate samples to be collected at that stage. He further stated that sputum can be used for a disease that had entered into the second week.

Several countries, companies and organizations have been at the forefront of the production of the PCR assay. In the United Kingdom, it was produced by the Public health of England and was distributed to several other laboratories (PHE, 2020). Similarly, Charité in Berlin developed another assay which was collaboration between Hong Kong and Europe. The assay produced was made available to the world by the WHO (Sheridan, 2020). The South Koreans were not left out as Kogene biotech produced an assay that was specific to the virus (Jeong, 2020). China, the United States, Canada and Russia all produced PCR detection kits that were used in their countries.

Currently, there are a few commercial tests that have been approved by WHO; Cobas SARSCoV-2 qualitative assay by Roche Molecular Systems, Coronavirus (COVID-19) genes igrtPCR assay by Primer design, Abbott Realtime SARSCoV-2 by Abbott Molecular and PerkinElmer SARS-CoV-2 Real-time RT-PCR Assay by SYM-BIO LiveScience (WHO, 2020).

ii. Isothermal Amplification Assays

This is a method where thermal cycling is not limitations as marked nucleic acid sequence are detected in an efficient and rapid order. There are several means with which isothermal amplification can be achieved most of which depend on alternate means by which primers pairing and prompting amplification reaction is permitted because the DNA is not heat constrained (Zhao et al., 2015). On prompting the reaction, the annealed DNA to the sequence of concern must be detached by the polymerase. This isothermal amplification principle has been applied in diagnosis and more recently in the diagnosis of COVID-19 (Hauck, 2020). They involve the use of specific DNA polymerases for splitting double-stranded DNA like the Bsu large piece, phi29, Klenowexoand large fragment polymerases of Bst which require a temperature of $25-40^{\circ} \mathrm{C}$ and $50-65^{\circ} \mathrm{C}$ reactions respectively. However, reverse transcriptase is added to the reaction which is well-suited when an RNA needs to be detected solely to preserve the manner of isothermal amplification (Zhao et al., 2015).

Six types of isothermal amplification assays exist, and they include Loop-Mediated Isothermal Amplification (LAMP) which utilizes 4-6 primers identifying 6-8 diverse regions of target DNA and well-suited for field diagnosis. Next is the Whole Genome Amplification (WGA) that utilizes the strand-displacement activity of DNA polymerases such as phi29 or Bst DNA Polymerase to permit vigorous amplification of the whole genome. Others include Strand Displacement Amplification (SDA), HelicaseDependent Amplification (HDA), Recombinase Polymerase Amplification (RPA) and Nucleic Acid Sequences Based Amplification (NASBA) (Martzy et al., 2019).

An automated assay that utilizes an isothermal nucleic acid amplification method produced by Abbott Diagnostics has only recently received the approval for mass production from the FDA (Hauck, 2020). The advantage of this test is that results are obtained in no more than 13 
minutes (Hauck, 2020). There is ongoing research on the use LAMP as it also found to be less expensive, time-consuming and can be used to detect viral RNA directly from swabs without necessarily being purified.

\section{B. Serology}

The antibodies IgG and IgM are produced in the advent of an infection as a possible defence mechanism. In SARS-CoV-2, the IgM and the IgG are evident in the blood from few days to 10-14 days after infection respectively (FDA, 2020). As regards IgM, its level as the infection progress is not well understood while levels of IgG are usually highest around day 28 following the start of the infection (FDA, 2020).

This antibody test is cheaper and rapid compared to PCR based method. It is used to predict or monitor progression of the disease in the community as well as knowing the immunity status. The downside as stated by Drosten (2020) is that length and duration of the immune response are not understood. In a similar note, Mallapaty (2020) stated that the duration of immunity developed by a person is unclear since it is believed that the probability ofreinfectionfew months later is minimal. Furthermore, the antibodies protecting 10 out of 175 patients in China recuperating from COVID-19 were not visible even though they had minor symptoms.

Many antibody detection tests are being developed at different stages in many countries. Some of these tests had approval by the countries agencies for clinical use under urgency (Mallapaty, 2020). Several types of serological assays exist and can produce results in minutes. The Rapid diagnostic test (RDT), a qualitative lateral flow method is one of such tests available. It can be used to detect antigens or antibodies and very useful in determining the antibody titres. Cellex and Chembio are examples of RDT that produce result between 10-30 minutes and approved by FDA (FDA, 2020).

ELISA is another test that is carried out in the laboratory and it is both qualitative and quantitative methods. The test principle is that it is dependent on the targeted viral protein being coated on a plate after samples are incubated with the protein. The presence of the viral protein will bound to the antibodies which will then produce a colour when more antibodies are added to the complex. The ELISA test mostly detects COVID-19 patient antibodies. An example of the ELISA test is the test by Ortho and Mount Sinai which can produce reads between 1-5 hours (Hopkins, 2020).

The neutralization assay depends entirely on cell culture which seeks to inhibit the progression of the viral infection into the cells and can be used to detect active antibodies even after the patient must have been cured. This method is based on using a reduced concentration of antibody as a medium where virus and cell can grow while observing the quantity of antibody that inhibits viral replication. Result for this can be produced between 3-5 days (Hopkins, 2020).

The chemiluminescent immunoassay is carried out in the laboratory, quantitative, can detect several antibodies and allows light to be emitted once the sample is mixed with an identified viral protein, reagents buffer and precise enzyme antibodies that are labelled. The amount of antibodies present is determined by the quantity of light emitted (Hopkins, 2020). Result for this can be produced between 1-2 hours (Hopkins, 2020). The table shows the different types of the serological test currently available or in research stage worldwide.

\section{Medical Imaging}

COVID-19 causes inflammation of the lungs and chest computed tomography(CT) scans may be used as part of the investigations, however it is not recommended for all patients as previous study highlighted the non-specificity of radiologic findings in COVID-19 (Salehi et al. (2020). As the disease progresses, subpleural ascendency, crazy tiling and merging may occur. Initial CT is characterised by a two-sided multilobar, ground-glass dullness distributed peripherally and asymmetrically (Lee et al., 2020).

\section{COVID-19 Outbreak in Malaysia}

Malaysia had its first case of COVID-19 on the $24^{\text {th }}$ of January, 2020, a traveller from China who transited through Singapore (Sipalan and Holmes, 2020). Before the case was detected, the Malaysian Institute for Medical Research (IMR) had optimised SARS-CoV-2 primers and probesSARS-CoV-2 based on the genetic sequences released by Chinese researchers earlier and subsequently by WHO. 
Table 2: Some Serological Test From Around the World

\begin{tabular}{|c|c|c|c|}
\hline Test type & Country & Manufacturer & $\begin{array}{ll}\text { Sensitivity } & (\mathrm{S}) \\
\text { specificity (SP) (\%) }\end{array}$ \\
\hline RDT & US and China & Cellex & $\begin{array}{l}S=93.8 \\
S P=95.6\end{array}$ \\
\hline RDT & US & Chembio & - \\
\hline ELISA & US & $\begin{array}{l}\text { Ortho-Clinical } \\
\text { Diagnostics }\end{array}$ & $\begin{array}{l}S=87.5 \\
S P=100\end{array}$ \\
\hline ELISA & USA & Mount Sinai Laboratory & - \\
\hline RDT & USA & $\begin{array}{l}\text { Autobio Diagnostics Co. } \\
\text { and Hardy Diagnostics) }\end{array}$ & $\begin{array}{l}S=95.7(\lg M) \text { and } 99(\lg G) \\
S P=99 \text { (both } \lg M \text { and } \operatorname{lgg})\end{array}$ \\
\hline ELISA & USA & DiaSorin Inc. & $\begin{array}{l}S=90-97 \\
S P=98\end{array}$ \\
\hline ELISA & USA & Bio-Rad & $\begin{array}{l}S=98 \\
S P=99\end{array}$ \\
\hline $\begin{array}{l}\text { Electro- } \\
\text { chemiluminescence } \\
\text { immunoassay (ECLIA) }\end{array}$ & $\begin{array}{l}\text { US- } \\
\text { Switzerland }\end{array}$ & Roche & $\begin{array}{l}S=100 \\
S P=99.81\end{array}$ \\
\hline ELISA & Germany & Euroimmun AG & $\begin{array}{l}\mathrm{S}=90 \text { by } \mathrm{NCl} \text { validation } \\
\mathrm{SP}=100 \text { by } \mathrm{NCl} \text { validation }\end{array}$ \\
\hline $\begin{array}{l}\text { Microsphere } \\
\text { immunoassay }\end{array}$ & USA & $\begin{array}{l}\text { Wadsworth Center, New } \\
\text { York State Department } \\
\text { of Health }\end{array}$ & $\begin{array}{l}S=\text { Not mentioned } \\
S P=93-100\end{array}$ \\
\hline $\begin{array}{l}\text { RDT, solid phase } \\
\text { immunochromatographic } \\
\text { assay }\end{array}$ & USA/China & $\begin{array}{l}\text { Aytu Biosciences and } \\
\text { Orient Gene Biotech }\end{array}$ & $\begin{array}{l}S=87.9(\operatorname{lgG}) \text { and } 97.2(\lg M) \\
S P=100 \text { (Both) }\end{array}$ \\
\hline Neutralization assay & Singapore & Singapore/ Wang Lab & $\begin{array}{l}\mathrm{S}=90 \\
\mathrm{SP}=\end{array}$ \\
\hline Lateral flow assay (RDT) & China & $\begin{array}{l}\text { Guangzhou Wondfo } \\
\text { Biotech }\end{array}$ & - \\
\hline $\begin{array}{l}\text { RDT (colloidal gold } \\
\text { lateral flow assay) }\end{array}$ & China & $\begin{array}{l}\text { Guangdong Hecin- } \\
\text { Scientific }\end{array}$ & - \\
\hline RDT & China & Dynamiker & - \\
\hline RDT & $\begin{array}{l}\text { The Republic } \\
\text { of Korea }\end{array}$ & SD Biosensor & $\begin{array}{l}S=82 \\
S P=97\end{array}$ \\
\hline ELISA & USA & $\begin{array}{l}\text { MayoClinic/University of } \\
\text { Minnesota }\end{array}$ & - \\
\hline $\begin{array}{l}\text { RDT (colloidal gold } \\
\text { lateral flow assay) }\end{array}$ & $\begin{array}{l}\text { The Republic } \\
\text { of Korea }\end{array}$ & Sugentech & $\begin{array}{l}S=91 \\
S P=96.7\end{array}$ \\
\hline RDT, prescreen step & Singapore & Sensing self & $\begin{array}{l}S=82 \\
S P=96\end{array}$ \\
\hline ELISA & UK & $\begin{array}{l}\text { Adams et al (Liverpool } \\
\text { School of Tropical } \\
\text { Medicine and Hygiene) }\end{array}$ & $\begin{array}{l}S=100 \\
S P=\end{array}$ \\
\hline RDT & Canada & Artron & $\begin{array}{l}S=93.4 \\
S P=97.7\end{array}$ \\
\hline $\begin{array}{l}\text { Dipstick (lateral flow } \\
\text { assay) }\end{array}$ & Belgium & CorisBio concept & $\begin{array}{l}S=60 \\
S P=99\end{array}$ \\
\hline
\end{tabular}

This was done in preparing the country for COVID-19. RT-PCR method was used in the diagnosis of what later became Malaysia's index case of COVID-19 (Abdullah, 2020).

In early March, few imported cases were detected followed by local cases. The local cases were believed to have emerged from a big religious gathering in Kuala Lumpur causing a sharp rise in the number of cases and UMYU Journal of Microbiology Research exportation of cases to border countries. By mid-March, 2020 there were over two thousand cases in Malaysia and was spread across every state resulting in Malaysia having the greatest number of infections in South East Asia (Sipalan and Holmes, 2020).

In early January, The Ministry of Health and National Security Council of Malaysia were put into action to coordinate COVID-19 crisis www.ujmr.umyu.edu.ng 
preparedness. The tasks include setup laboratories, protocols or guidelines for handling patients in primary healthcare setting and designated COVID-19 centres. As the disease spread, a Movement Control Order (MCO) was proclaimed to curb the spread of the disease through social distancing. The MCO was meant to last for about two weeks but was repeatedly extended following the spread of the disease (Wern Jun 2020). When the active cases reduced, the MCO has been lifted and a new Conditional Movement Control Order is in place hopefully until conditions improve.

Malaysia's readiness to combat COVID-19 cannot be overemphasised. They have been proactive right from the onset. This is evident in the activities of the National Crisis Preparedness and Response Centre (CPRC) whom as early as $5^{\text {th }}$ January got to work while setting up over 50 hospitals for the COVID-19 screening (Abdullah, 2020). More than 20 government-owned hospitals were tasked with the screening of suspected patients and confirmation of the test. As the disease progressed nationwide, over 400 locations were being used by the government as quarantine centres. More bed spaces and ICU beds were created, more hospitals as low-risk centres were also created followed by apportioning over a thousand ventilators as at early May (Ong, 2020).

Malaysia as at early April sort to increase their testing capacity to at least 16,500 tests daily. A group of Laboratories in Malaysia and public universities with equipped diagnostic laboratories were to provide that assistance to achieve the mark (Rafidi, 2020).

Malaysia is listed as one of the countries where WHO drug trials for COVID-19 will take place termed the Solidarity trial. This trial would include the testing of the effectiveness of promising drugs like remdesivir, lopinavir, hydroxychloroquine, interferon-beta and chloroquine (Abdullah, 2020).

Malaysia will begin their local vaccine testing as cooperation between IMR, Malaysian Vaccines and Pharmaceuticals (MVP) and Universiti Malaya Tropical Infectious Diseases Research and Education Centre (TIDREC). TIDREC has one of the countries biosafety level 3 laboratories where the testing will be done. TIDREC is known for its reputation in handling highly infectious viruses like MERS-CoV, infectious bronchitis virus (IBV) and Nipah virus (Minion, 2020).

Below is a table showing the summary of COVID-19 cases in Malaysia.

Table 3: COVID-19 Cases in Malaysia as at $3^{\text {rd }}$ June 2020

\begin{tabular}{llllllll}
\hline Country & $\begin{array}{l}\text { Confirmed } \\
\text { Cases }\end{array}$ & $\begin{array}{l}\text { Active } \\
\text { cases }\end{array}$ & Discharged & Death & $\begin{array}{l}\text { Recovery } \\
\text { rate (\%) }\end{array}$ & $\begin{array}{l}\text { Fatality } \\
\text { rate (\%) }\end{array}$ & $\begin{array}{l}\text { Samples } \\
\text { tested }\end{array}$ \\
\hline Malaysia & 7,970 & 1,324 & 6,531 & 115 & 81.90 & 1.40 & 567,535 \\
\hline
\end{tabular}

\section{COVID-19 Cases in Malaysia as of 3rd June, 2020}

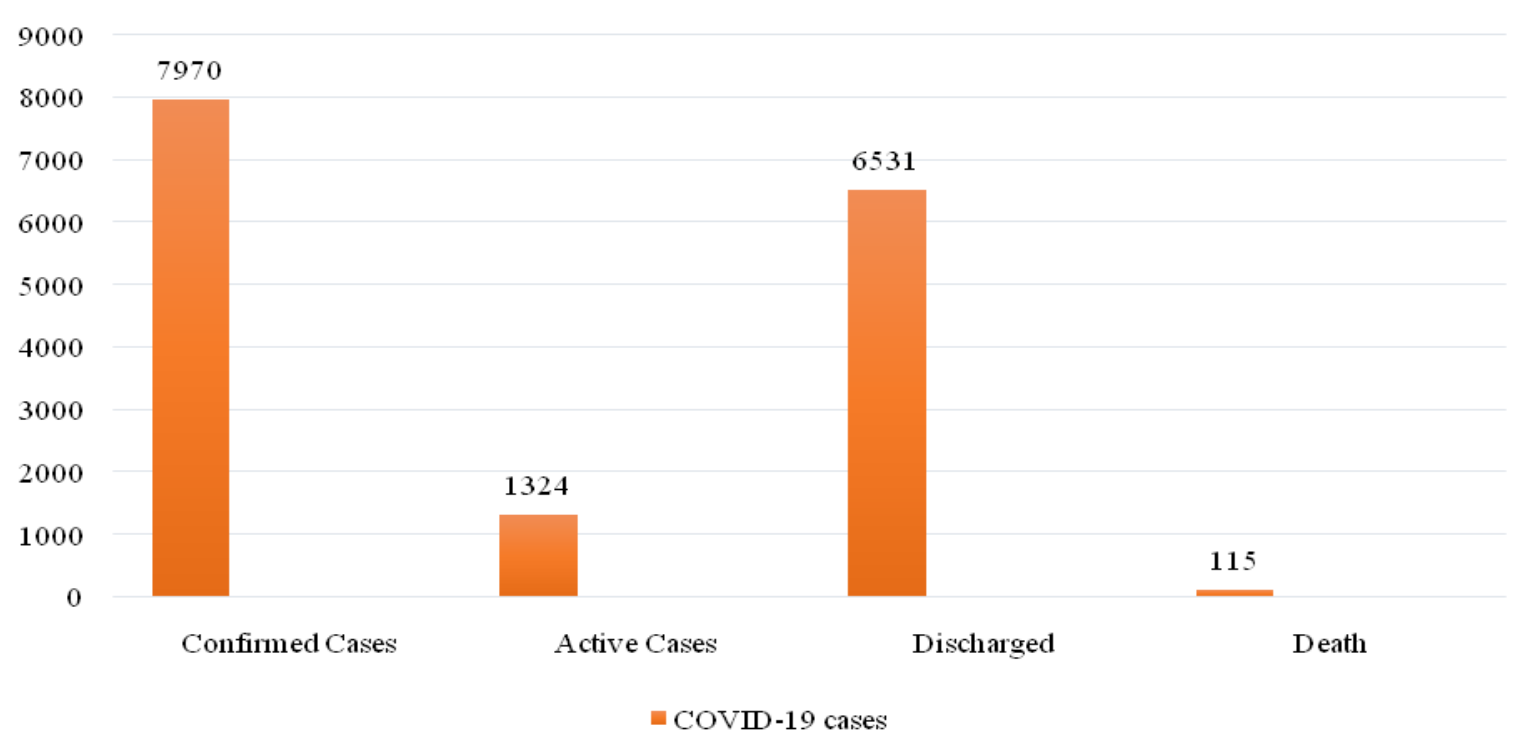

Fig I: COVID-19 Cases in Malaysia as of $3^{\text {rd }}$ June 2020 
According to the number of deaths, 89 were males accounting for $77.4 \%$ while 26 were females accounting for $22.6 \%$. The total

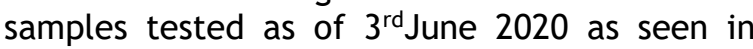

Table 3, indicates that Malaysia has the highest number of COVID-19 test performed in the whole of Southeast Asia.

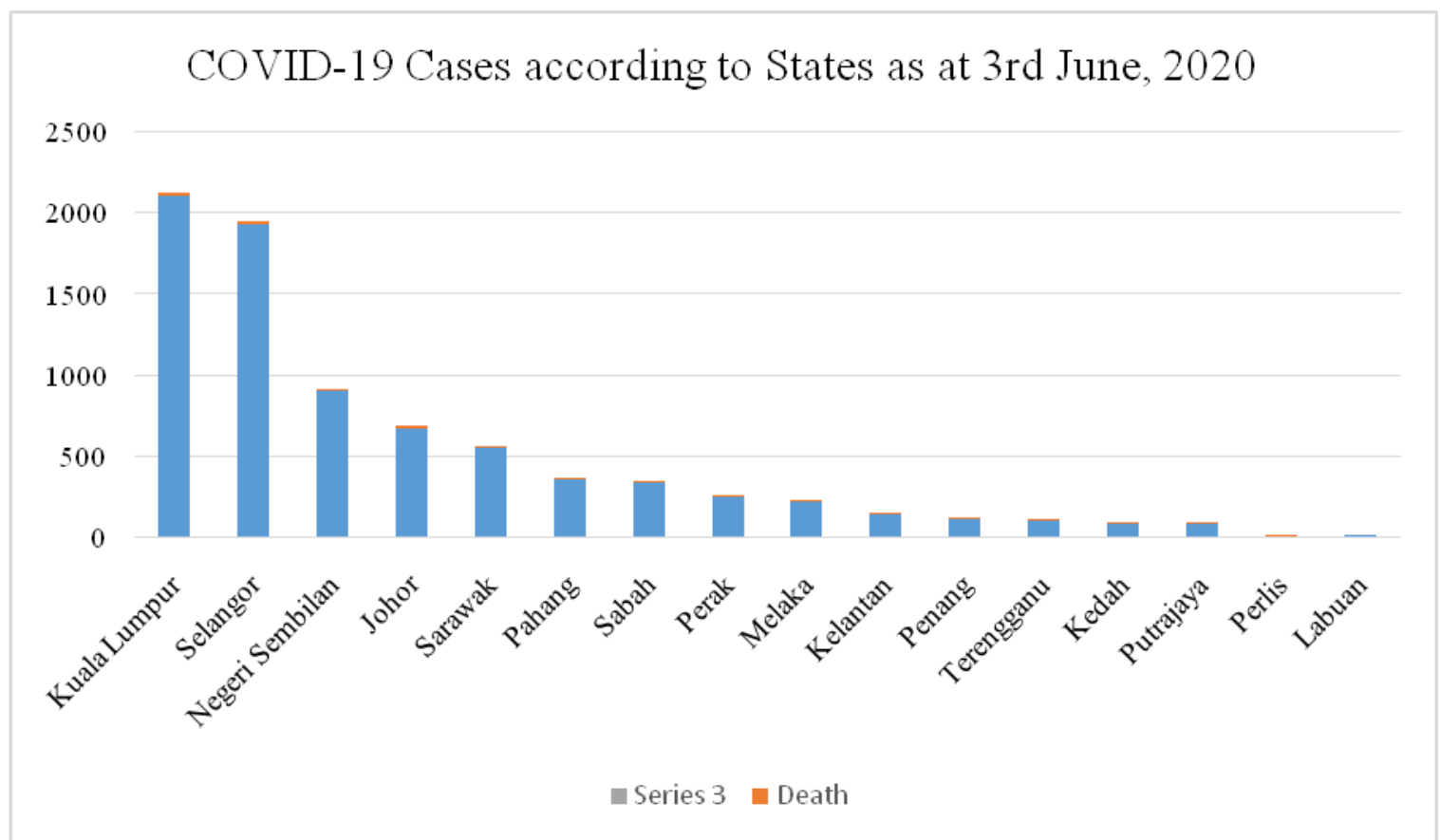

Fig II: COVID-19 Cases According To States as of $3^{\text {rd }}$ June 2020

\section{Conclusion and Future Thoughts}

As of $3^{\text {rd }}$ June, Malaysia has the most tests done in the whole of ASEAN country. A lot still needs to be done in the management and improved testing of COVID-19 although more laboratories are being established to improve testing. Malaysia's handling of COVID-19 is for a lack of better word exceptional, reason why they are opening their economy gradually. RT-qPCR is considered the recommended and gold standard test for the confirmation of COVID-19 cases, however, it cost the government a lot of money for to set up the laboratory facilities and technical manpower. LAMP which produces results in a shorter time is in the research stage and when completed, will shorten the time for case confirmation. RDT should be validated as its use will save many poor countries who

\section{REFERENCES}

Abbasi, J. (2020). The Promise and Peril of Antibody Testing for COVID-19. JAMA Journal of the American Medical Association.

https: / / doi.org/10.1001/jama.2020.6170

Abdullah, N.H. (2020). Current Status on the Coronavirus Disease 2019 (COVID-19) Situation in Malaysia". From the Desk of the Director-General of Health Malaysia. 2 May cannot afford the molecular testing. RDT is cheaper and more applicable at point of care testing. It is useful for screening and surveillance as it narrows down the population requiring confirmation test using RT-qPCR. The pace for vaccine and drug development should be increased as only a vaccine or a drug can return the normalcy once enjoyed. Without a drug or a vaccine, COVID-19 is here to stay and we must adapt to the new norm.

Acknowledgment

This review was funded by the Universiti Sains Malaysia Fellowship.

\section{Conflict of interest}

The authors declare no conflict of interest.

Ethical approval

This author of this article did not carry out any experiments involving humans or animals.

2020. Retrieved 17 May 2020.

Abdullah, N.H. (2020). "Kenyataan Akhbar KPK 6 Januari 2020 - Makluman Kejadian Kejadian Kluster Radang Paru-Paru (Pneumonia) di Wuhan, Republik Rakyat China". From the Desk of the Director-General of Health Malaysia. Retrieved 17 May 2020.

Agostini, M. L., Andres, E. L., Sims, A. C., Graham, R. L., Sheahan, T. P., Lu, X., ... Denison, M. R. (2018). Coronavirus www.ujmr.umyu.edu.ng 
susceptibility to the antiviral remdesivir (GS-5734) is mediated by the viral polymerase and the proofreading exoribonuclease. MBio, 9(2). https://doi.org/10.1128/mBio.00221-18

Alsaad, K. O., Hajeer, A. H., Al Balwi, M., Al Moaiqel, M., Al Oudah, N., Al Ajlan, A., ... Arabi, Y. M. (2018). Histopathology of Middle East respiratory syndrome coronavirus (MERS-CoV) infection clinicopathological and ultrastructural study. Histopathology, 72(3), 516-524. https: / / doi.org/10.1111/his.13379

Bustin, S. A. (2005). Real-time, fluorescencebased quantitative PCR: A snapshot of current procedures and preferences. Expert Review of Molecular Diagnostics, Vol. 5, pp. 493-498. https://doi.org/10.1586/14737159.5.4.493

Canton, J., Fehr, A. R., Fernandez-Delgado, R., Gutierrez-Alvarez, F. J., Sanchez-Aparicio, M. T., García-Sastre, A., ... Sola, I. (2018). MERS-CoV 4b protein interferes with the NF-kB-dependent innate immune response during infection. PLOS Pathogens, 14(1), e1006838.

https://doi.org/10.1371/journal.ppat.1006 838

Centre for Disease Control (2020). Testing for COVID-19 | CDC. (n.d.). Retrieved May 17, 2020,

https://www.cdc.gov/coronavirus/2019ncov/symptoms-testing/testing.html

Cong, Y., Hart, B. J., Gross, R., Zhou, H., Frieman, M., Bollinger, L., ... Holbrook, M. R. (2018). MERS-CoV pathogenesis and antiviral efficacy of licensed drugs in human monocyte-derived antigenpresenting cells. PLOS ONE, 13(3). https://doi.org/10.1371/journal.pone.0194 868

Damon, W. (2020). "World leaders urge cooperation in vaccine hunt, raise $\$ 8$ billion". Yahoo Finance. Retrieved 17 May 2020.

Discovery of T-Cell Infection and Apoptosis by Middle East Respiratory Syndrome Coronavirus. (2020). Retrieved May 17, 2020, from https://www.ncbi.nlm.nih.gov/pmc/article s/PMC4760413/

Drosten, C., Seilmaier, M., Corman, V. M., Hartmann, W., Scheible, G., Sack, S., ... Wendtner, C. M. (2013). Clinical features and virological analysis of a case of Middle East respiratory syndrome coronavirus infection. The Lancet Infectious Diseases, 13(9),

745-751.

UMYU Journal of Microbiology Research https: / /doi.org/10.1016/S1473-

3099(13)70154-3

Drosten, C. (2020). "Coronavirus-Update Folge 22" (PDF). NDR. Archived (PDF) from the original on 31 March 2020. Retrieved 17 May 2020.

Durai, P., Batool, M., Shah, M., \& Choi, S. (2015). Middle East respiratory syndrome coronavirus: transmission, virology and therapeutic targeting to aid in outbreak control. Experimental \& Molecular Medicine, Vol. 47, p. e181. https://doi.org/10.1038/emm.2015.76

Fehr, A. R., \& Perlman, S. (2015). Coronaviruses: An overview of their replication and pathogenesis. In Coronaviruses: Methods and Protocols (pp. 1-23). https://doi.org/10.1007/978-1-49392438-7_1

Food and Drug Administration (2020). "Cellex Emergency Use Authorization". Retrieved 17 May 2020.

Food and Drug Administration (2020). Remdesivir EUA Letter of Authorization (PDF). 1 May 2020. Retrieved 17 May 2020.

Garoff, H., Hewson, R., \& Opstelten, D.-J. E. (1998). Virus Maturation by Budding. Microbiology and Molecular Biology Reviews, 62(4), 1171-1190. https://doi.org/10.1128/mmbr.62.4.11711190.1998

Global Progress on COVID-19 Serology-Based Testing. (2020). Retrieved May 17, 2020, from

https: / / www.centerforhealthsecurity.org/r esources/COVID-19/serology/Serologybased-tests-for-COVID-19.html\#sec2

Grenfell, R \& Drew, T (2020). "Here's Why It's Taking So Long to Develop a Vaccine for the New Coronavirus". Science Alert. Archived from the original on 28 February 2020. Retrieved 17 May 2020. Available from: https: / / www.medrxiv.org/content/10.1101 /2020.03.17.20037788v1.full.pdf

Hauck, J. (2020). Coronavirus: FDA authorizes Abbott Labs' 5-minute COVID-19 test. (n.d.). Retrieved May 17, 2020, from https://www.usatoday.com/story/news/he alth/2020/03/28/coronavirus-fdaauthorizes-abbott-labs-fast-portable-covidtest/2932766001/

Holden, M. J., \& Wang, L. (2008). Quantitative Real-Time PCR: Fluorescent Probe Options and Issues. In Standardization and Quality Assurance in Fluorescence Measurements II (pp. 489-508). https: / /doi.org/10.1007/4243_2008_046

Hsu, L. Y., Lee, C. C., Green, J. A., Ang, B., www.ujmr.umyu.edu.ng 
Paton, N. I., Lee, L., ... Leo, Y. S. (2003). Severe acute respiratory syndrome (SARS) in Singapore: Clinical features of the index patient and initial contacts. Emerging Infectious Diseases, 9(6), 713-717. https: / / doi.org/10.3201/eid0906.030264

Huang, C., Wang, Y., Li, X., Ren, L., Zhao, J., Hu, Y., ... Cao, B. (2020). Clinical features of patients infected with 2019 novel coronavirus in Wuhan, China. The Lancet, 395(10223), 497-506. https: / /doi.org/10.1016/S01406736(20)30183-5

Jeon, S., Ko, M., Lee, J., Choi, I., Byun, S. Y., Park, S., ... Kim, S. (2020). Identification of antiviral drug candidates against SARS-CoV2 from FDA-approved drugs. Antimicrobial Agents and Chemotherapy. https: / / doi.org/10.1128/AAC.00819-20

Jeong, S. (2020). "Korea approves 2 more COVID-19 detection kits for urgent use". Korea Biomedical Review.

Lau, S. K. P., Lau, C. C. Y., Chan, K. H., Li, C. P. Y., Chen, H., Jin, D. Y., ... Yuen, K. Y. (2013). Delayed induction of proinflammatory cytokines and suppression of innate antiviral response by the novel Middle East respiratory syndrome coronavirus: Implications for pathogenesis and treatment. Journal of General Virology, 94(PART 12), 2679-2690. https://doi.org/10.1099/vir.0.055533-0

Lee, E. Y. P., Ng, M. Y., \& Khong, P. L. (2020). COVID-19 pneumonia: what has CT taught us? The Lancet Infectious Diseases, Vol. 20, pp. 384-385. https: / / doi.org/10.1016/S14733099(20)30134-1

Li, G., \& De Clercq, E. (2020). Therapeutic options for the 2019 novel coronavirus (2019-nCoV). Nature Reviews. Drug Discovery, Vol. 19, pp. 149-150. https: / /doi.org/10.1038/d41573-02000016-0

Mackay, I. M., \& Arden, K. E. (2015). MERS coronavirus: diagnostics, epidemiology and transmission. Virology Journal, Vol. 12, pp. 1-21. https://doi.org/10.1186/s12985-0150439-5

Mallapaty, S. (2020). Will antibody tests for the coronavirus really change everything? Nature. https://doi.org/10.1038/d41586020-01115-z

Martzy, R., Kolm, C., Krska, R., Mach, R. L., Farnleitner, A. H., \& Reischer, G. H. (2019). Challenges and perspectives in the application of isothermal DNA amplification methods for food and water analysis.

UMYU Journal of Microbiology Research
Analytical and Bioanalytical Chemistry, 411(9), 1695-1702. https://doi.org/10.1007/s00216-018-1553-1

Menachery, V. D., Eisfeld, A. J., Schäfer, A., Josset, L., Sims, A. C., Proll, S., ... Baric, R. S. (2014). Pathogenic influenza viruses and coronaviruses utilize similar and contrasting approaches to control interferon-stimulated gene responses. MBio, 5(3). https://doi.org/10.1128/mBio.01174-14

Menachery, V. D., Schäfer, A., BurnumJohnson, K. E., Mitchell, H. D., Eisfeld, A. J., Walters, K. B., ... Baric, R. S. (2018). MERS-CoV and H5N1 influenza virus antagonize antigen presentation by altering the epigenetic landscape. Proceedings of the National Academy of Sciences of the United States of America, 115(5), E1012E1021. https://doi.org/10.1073/pnas.1706928115

Minion, R.D. (2020). "Institute For Medical Research Malaysia Begins Testing Local Vaccines To Treat COVID-19". RojakDaily. Archived from the original on 9 April 2020. Retrieved 17 May 2020.

Ong, J. (2020). "Putrajaya gazettes 409 facilities as Covid-19 quarantine stations". The Malay Mail. Archived from the original on 22 March 2020. Retrieved 17 May 2020.

Park, J. E., Li, K., Barlan, A., Fehr, A. R., Perlman, S., McCray, P. B., \& Gallagher, T. (2016). Proteolytic processing of middle east respiratory syndrome coronavirus spikes expands virus tropism. Proceedings of the National Academy of Sciences of the United States of America, 113(43), 1226212267. https://doi.org/10.1073/pnas. 1608147113

Paules, C. I., Marston, H. D., \& Fauci, A. S. (2020). Coronavirus Infections-More Than Just the Common Cold. JAMA - Journal of the American Medical Association, Vol. 323, pp. 707-708. https://doi.org/10.1001/jama.2020.0757

Public Health of England (2020). PHE novel coronavirus diagnostic test rolled out across UK". GOV.UK. Retrieved 17 May 2020

Pyrc, K., Berkhout, B., \& van der Hoek, L. (2007). Identification of new human coronaviruses. Expert Review of AntiInfective Therapy, 5(2), 245-253. https://doi.org/10.1586/14787210.5.2.245

Rabouw, H. H., Langereis, M. A., Knaap, R. C. M., Dalebout, T. J., Canton, J., Sola, I., ... van Kuppeveld, F. J. M. (2016). Middle East Respiratory Coronavirus Accessory Protein 4a Inhibits PKR-Mediated Antiviral Stress Responses. PLoS Pathogens, 12(10). www.ujmr.umyu.edu.ng 
https://doi.org/10.1371/journal.ppat.1005 982

Rafidi, R. (2020). "Malaysian varsities join Covid-19 testing battle". New Straits Times. Archived from the original on 9 April 2020. Retrieved 17 May 2020.

Raj, K., Rohit, Ghosh, A., \& Singh, S. (2020). Coronavirus as silent killer: recent advancement to pathogenesis, therapeutic strategy and future perspectives. VirusDisease, p. 1. https://doi.org/10.1007/s13337-020-005804

Raj, V. S., Osterhaus, A. D. M. E., Fouchier, R. A. M., \& Haagmans, B. L. (2014). MERS: Emergence of a novel human coronavirus. Current Opinion in Virology, Vol. 5, pp. 5862. https: / /doi.org/10.1016/j.coviro.2014.01.0 10

Ratcliff, R. M., Chang, G., Kok, T. W., \& Sloots, T. P. (2007). Molecular diagnosis of medical viruses. Current Issues in Molecular Biology, Vol. 9, pp. 87-102. https://doi.org/10.21775/cimb.009.087

Salehi, S., Abedi, A., Balakrishnan, S., \& Gholamrezanezhad, A. (2020). Coronavirus Disease 2019 (COVID-19): A Systematic Review of Imaging Findings in 919 Patients. AJR. American Journal of Roentgenology, 1-7. https: / /doi.org/10.2214/AJR.20.23034

Sanjuán, R., \& Domingo-Calap, P. (2016). Mechanisms of viral mutation. Cellular and Molecular Life Sciences, Vol. 73, pp. 44334448. https://doi.org/10.1007/s00018-0162299-6

Scavone, C., Brusco, S., Bertini, M., Sportiello, L., Rafaniello, C., Zoccoli, A., ... Capuano, A. (2020). Current pharmacological treatments for COVID-19: what's next? British Journal of Pharmacology. https://doi.org/10.1111/bph.15072

Sheridan, C. (2020). Coronavirus and the race to distribute reliable diagnostics. Nature Biotechnology, Vol. 38, pp. 382-384. https://doi.org/10.1038/d41587-02000002-2

Sipalan, J. \& Holmes, S. (2020). "Malaysia confirms first cases of coronavirus infection". Reuters. Archived from the original on 18 February 2020. Retrieved 17 May 2020.

Thanh Le, T., Andreadakis, Z., Kumar, A., Gómez Román, R., Tollefsen, S., Saville,
M., \& Mayhew, S. (2020). The COVID-19 vaccine development landscape. Nature Reviews Drug Discovery. https: / /doi.org/10.1038/d41573-02000073-5

To, K. K. W., Hung, I. F. N., Chan, J. F. W., \& Yuen, K. Y. (2013). From SARS coronavirus to novel animal and human coronaviruses. Journal of Thoracic Disease, 5(SUPPL.2), S103. https://doi.org/10.3978/j.issn.20721439.2013.06.02

Wang, L., Byrum, B., \& Zhang, Y. (2014). Detection and genetic characterization of delta coronavirus in pigs, Ohio, USA, 2014. Emerging Infectious Diseases, 20(7), 12271230.

https: / / doi.org/10.3201/ eid2007.140296

Wern Jun, S. (2020). "Movement control order not a lockdown, says former health minister". The Malay Mail. Archived from the original on 17 March 2020. Retrieved 17 May 2020.

World Health Organization (2020). COVID-19 situation reports. (n.d.). Retrieved May 16, 2020, from https: / /www. who.int/emergencies/disease s/novel-coronavirus-2019/situation-reports

World Health Organization (2020). WHO lists two COVID-19 tests for emergency use. (n.d.). Retrieved May 17, 2020, from https: / /www. who.int/newsroom/detail/07-04-2020-who-lists-twocovid-19-tests-for-emergency-use

Xia, S., Liu, Q., Wang, Q., Sun, Z., Su, S., Du, L., ... Jiang, S. (2014). Middle East respiratory syndrome coronavirus (MERSCoV) entry inhibitors targeting spike protein. Virus Research, 194, 200-210. https://doi.org/10.1016/j.virusres.2014.10 .007

Yang, Y., Zhang, L., Geng, H., Deng, Y., Huang, B., Guo, Y., ... Tan, W. (2013). The structural and accessory proteins $M$, ORF $4 \mathrm{a}$, ORF 4b, and ORF 5 of Middle East respiratory syndrome coronavirus (MERSCoV) are potent interferon antagonists. Protein and Cell, 4(12), 951-961. https: / / doi.org/10.1007/s13238-013-3096-8

Zhao, Y., Chen, F., Li, Q., Wang, L., \& Fan, C. (2015). Isothermal Amplification of Nucleic Acids. Chemical Reviews, Vol. 115, pp. 12491-12545. https: / /doi.org/10.1021/acs.chemrev.5b00 428 